\title{
A note on A Modern Guide to Citizen's Basic Income
}

The writing of this history overlapped to some extent with the writing of a multidisciplinary study of Basic Income: A Modern Guide to Citizen's Basic Income: A multidisciplinary approach, which was published by Edward Elgar Publishing in 2020. The publisher describes the book like this:

Debate on the desirability, feasibility and implementation of a Citizen's Basic Income - an unconditional, nonwithdrawable and regular income for every individual - is increasingly widespread among academics, policymakers, and the general public. There are now numerous introductory books on the subject, and others on particular aspects of it. This book provides something new: It studies the Citizen's Basic Income proposal from a variety of different disciplinary perspectives: the economics of Citizen's Basic Income, the sociology of Citizen's Basic Income, the politics of Citizen's Basic Income, and so on. Each chapter discusses the academic discipline, and relevant aspects of the debate, and asks how the discipline enhances our understanding, and how the Citizen's Basic Income debate might contribute to the academic discipline.

Of particular interest to readers of this book might be Chapter 3, which studies the history of history-writing, from political history, through social history, to economic history, and concludes that history-writing is the construction of narratives influenced by contemporary agendas and backed up by evidence. Questions are then set: Is the history of Basic Income a subdiscipline of history, or of social history, or of economic history? What are the agendas that historians bring to their history-writing? What are the data that they seek to back up their arguments? Should a history of Basic Income be a history of the idea of a Basic Income, of policy debates, or of practical experiments? To what extent should the history be located in the broader history of existing tax and benefits systems? To what extent should 'close cousins', such as Negative Income Tax, be included? Five histories of Citizen's Basic Income are then evaluated against these questions, and conclusions are drawn.

Readers of this history might find it interesting to evaluate it in relation to the questions asked in Chapter 3 of A Modern Guide to Citizen's Basic Income: A multidisciplinary approach. 